\title{
Effect of Water and Fertilizer Regulation on the Soil Available P Content in Winter Wheat at West Lake Plain and Baiyang Lake in China
}

\author{
Jinbo Zhao', Ming Chen'1, Jiawei Li², Jinghua Zhou ${ }^{3 *}$ \\ ${ }^{1}$ State Key Laboratory of Environment Simulation and Pollution Control, School of Environment, Beijing Normal University, \\ Beijing, China \\ ${ }^{2}$ School of Real Estate, Beijing Normal University Zhuhai Campus, Zhuhai, China \\ ${ }^{3}$ State Key Laboratory of Environment Simulation and Pollution Control, School of Environment, Tsinghua University, Beijing, \\ China \\ Email: *shc-den@tsinghua.edu.cn
}

How to cite this paper: Zhao, J.B., Chen, M., Li, J.W. and Zhou, J.H. (2020) Effect of Water and Fertilizer Regulation on the Soil Available P Content in Winter Wheat at West Lake Plain and Baiyang Lake in China. Open Access Library Journal, 7: e6774.

https://doi.org/10.4236/oalib.1106774

Received: September 3, 2020

Accepted: October 17, 2020

Published: October 20, 2020

Copyright $\odot 2020$ by author(s) and Open Access Library Inc.

This work is licensed under the Creative Commons Attribution International License (CC BY 4.0).

http://creativecommons.org/licenses/by/4.0/

\begin{abstract}
Water and nutrients are the basic requirements for crop growth, which are mutually interacting and restricted. This paper studied winter wheat (wheat breed: Ji wheat 22) on changes in soil nutrient leaching in the regulation measures of water and fertilizer (two irrigation methods: traditional irrigation (A) and water-saving irrigation (B); three fertilization factors: no fertilization (CK), traditional fertilization (FC) and optimized fertilization (FO)). The results showed that under the different water and fertilizer regulations, the nitrate concentration in the soil decreased with increasing soil depth. The soil nitrate concentration in the water-saving irrigation treatment was lower than that in the traditional irrigation treatment. During wheat growth, the accumulated amount of nitrogen and phosphorus in the plant increased constantly, reaching its maximum at the mature stage. This paper analyzes the environmental benefits of winter wheat irrigation and fertilization and provides a theoretical basis for rotation system efficiency and the sustainable production of winter wheat in a plain area.
\end{abstract}

\section{Subject Areas}

Agricultural Engineering, Environmental Sciences

\section{Keywords}

Fertilizer Phosphate Soil 


\section{Background and Significance}

Water deficiency is an important factor limiting the sustainable development of agriculture in Hebei Province [1] [2]. The per capita water resources and per mu water resources in Hebei Province cover one-eighth of the national average level. At the same time, the precipitation is not uneven, the interannual variation is large, and the precipitation is not evenly distributed within the year, approximately $80 \%$ of which is concentrated in June and August. In the rainy season, when rainfall concentrates, nonpoint source pollution leads to water eutrophication in Baiyang Lake, affecting water quality safety. However, the excessive application of phosphorus fertilizers is the main cause of agricultural nonpoint source pollution. Therefore, research on the migration regularity of fertilizer in the pedosphere and soil-water interface is of great significance for the control of agricultural nonpoint source pollution [3] [4] [5] [6].

The rational application of fertilizer can effectively increase the net photosynthetic rate, fertilizer absorption and utilization rate and yield of crops and improve crop water use efficiency [7]-[18]. However, the utilization rate of phosphorus fertilizers in crops in China is generally very low.

In view of the above practical problems of agricultural water resource shortages, agricultural nonpoint source pollution, water eutrophication, the lower utilization rate of phosphorus fertilizers and the decrease in grain nutrition, China has been studying the interaction effects of water and fertilizer, reasonable irrigation and fertilization over the years to achieve the purpose of "promoting fertilizer with water and adjusting water by using manure".

In this paper, the field location test was conducted in a winter wheat intensive planting area, West Lake Plain, Baiyang Lake. Through field experiments and indoor laboratory analyses, the characteristics of phosphorus transfer and leaching loss in farmland soils under different water and fertilizer regulations (irrigation modes and fertilization management conditions) were studied to provide a scientific basis for water savings and fertilization savings in the farmland, high water-fertilizer use efficiency, and phosphorus nonpoint source pollution reduction.

\section{Research Methods}

This experiment was carried out from October 2015 to June 2016 at Baizhuang Village. The experimental field belongs to the eastern monsoon zone semihumid continental climate, with an average annual temperature of $12.5^{\circ} \mathrm{C}$ and a frost-free period of approximately $280 \mathrm{~d}$. The rainfall is mainly concentrated in summer from June to August, accounting for $67.9 \%$ of the total rainfall per year. The basic physical and chemical properties of the experimental soil are shown in Table 1.

The variety of experimental wheat was "Ji wheat 22 ". Diammonium phosphate was used in the phosphatic fertilizer, urea was used in the nitrogenous fertilizer, and potassium chloride was used in the potash fertilizer. 
Table 1. The basic physical and chemical properties of the experimental soil.

\begin{tabular}{|c|c|c|c|c|c|c|c|}
\hline $\begin{array}{l}\text { Soil depth } \\
\quad(\mathrm{cm})\end{array}$ & $\begin{array}{l}\text { Nitrate } \\
(\mathrm{mg} / \mathrm{kg})\end{array}$ & $\begin{array}{l}\text { Alkali hydrolysis } \\
\qquad(\mathrm{mg} / \mathrm{kg})\end{array}$ & $\begin{array}{l}\text { Rapidly available } \\
\text { phosphorus } \\
(\mathrm{mg} / \mathrm{kg})\end{array}$ & $\begin{array}{c}\text { Rapidly available } \\
\text { potassium } \\
(\mathrm{mg} / \mathrm{kg})\end{array}$ & $\begin{array}{c}\text { Organic material } \\
\qquad(\mathrm{g} / \mathrm{kg})\end{array}$ & $\begin{array}{l}\text { Volume weight } \\
\qquad\left(\mathrm{g} / \mathrm{cm}^{3}\right)\end{array}$ & $\mathrm{pH}$ \\
\hline $20-40$ & 7.30 & 80.52 & 7.43 & 100.32 & 13.30 & 1.59 & 7.54 \\
\hline $40-60$ & 5.87 & 55.43 & 3.71 & 104.28 & 10.11 & 1.63 & 7.32 \\
\hline $60-80$ & 5.99 & 37.80 & 2.04 & 99.41 & 11.19 & 1.65 & 7.86 \\
\hline $80-110$ & 3.02 & 28.11 & 1.86 & 97.29 & 8.85 & 1.77 & 7.36 \\
\hline $110-140$ & 4.33 & 20.24 & 2.60 & 95.30 & 6.26 & 1.75 & 7.44 \\
\hline $140-170$ & 2.84 & 17.58 & 3.53 & 98.63 & 3.16 & 1.70 & 7.28 \\
\hline $170-200$ & 1.62 & 14.26 & 1.49 & 97.45 & 2.17 & 1.66 & 7.59 \\
\hline
\end{tabular}

The representative farmland was selected to arrange the field experiment in West Lake Plain, Baiyang Lake. Two regions were set for the treatment: traditional irrigation (A) and water-saving irrigation (B). Each region was divided into three regulatory factor split areas: no fertilization (CK), traditional fertilization (FC) and optimized fertilization (FO). Each treatment plot area was $9.5 \times$ $4.5=42.75 \mathrm{~m}^{2}$. Randomly arrange a total of 18 plots (three parallel trials), with an interval of $1 \mathrm{~m}$ between each plot, and set up a $2 \mathrm{~m}$ protection line at the periphery of the large area. The furrow water conveyance basin irrigation method was used in the traditional irrigation treatment, and a water meter was used to measure the irrigation amount. The water-saving irrigation treatment adopted the sprinkler irrigation method, which uses $30 \%$ less water than traditional irrigation. The two irrigation methods and the irrigation frequency were the same. The dose of the traditional fertilization and the optimized fertilization are shown in Table 2. All the phosphate and potassium fertilizers were applied in the form of base fertilizer for broadcast fertilization, with shallow plowing and earthing before wheat cultivation with a $70 \%$ bottom application of nitrogen fertilizer. The amount of nitrogen fertilizer topdressing was $70 \%$ in the wheat elongating stage combined with the irrigation. Other field management measures were conducted according to the peasant traditions.

Two ears of wheat in two $1 \mathrm{~m} \times 1 \mathrm{~m}$ squares of each plot were taken and threshed after air drying, and the yield and the thousand kernel weight (TKW) were measured. Another 15 continuous ears were taken to measure the ear grains. The winter wheat was sampled at the regreening, jointing, flowering, grain filling and maturation stages. Each sampling size was 0.5 single row plants per plot. The root system was cut off and put in a net bag. The deactivation of the enzymes was carried out for $30 \mathrm{~min}$ at $90^{\circ} \mathrm{C}$. It was dried to a constant weight at $75^{\circ} \mathrm{C}$ to measure the biomass. The soil moisture was taken from the 0 20, 20 - 40, 40 - 60, 60 - 80, 80 - 110, 110 - 140, $140-170$ and $170-200 \mathrm{~cm}$ soil layers, respectively, which was determined by using the drying method. A soil auger was used to take soil at a sampling depth of $200 \mathrm{~cm}$. The first $80 \mathrm{~cm}$ was applied by stratifying the samples every $20 \mathrm{~cm}$, and the latter $120 \mathrm{~cm}$ was applied 
Table 2. The experimental design of the winter wheat field.

\begin{tabular}{cccc}
\hline No. & Treatment & $\begin{array}{c}\text { Chemical fertilizer (N-P-K) } \\
\left(\mathrm{kg} / \mathrm{hm}^{2}\right)\end{array}$ & $\begin{array}{c}\text { Irrigation amount } \\
\left(\mathrm{m}^{3} / \mathrm{hm}^{2}\right)\end{array}$ \\
\hline 1 & A-CK & 0 & 2250 \\
2 & A-FC & $275-150-60$ & 2250 \\
3 & A-FO & $225-150-90$ & 2250 \\
4 & B-CK & 0 & 1500 \\
5 & B-FC & $275-150-60$ & 1500 \\
8 & B-FO & $225-150-90$ & 1500 \\
\hline
\end{tabular}

by stratifying the samples every $30 \mathrm{~cm}$. There were 8 samplings from 0 to 200 $\mathrm{cm}$, which were placed into numbered plastic bags.

Determination method: After the collected fresh soil sample was thoroughly mixed, $5 \mathrm{~g}$ of the fresh field soil was taken, and $50 \mathrm{~mL}$ of a $1 \mathrm{~mol} / \mathrm{L} \mathrm{KCl}$ solution was used for the digestion. The mixture was allowed to oscillate for $1 \mathrm{~h}$, and the available phosphorus content was determined using the $0.5 \mathrm{~mol} / \mathrm{L}$ sodium bicarbonate extraction-Mo-Sb colorimetric method.

\section{Result and Analysis}

In the wheat growth stage, regardless of whether traditional irrigation (A) or water-saving irrigation (B) was used, the content of available phosphorus in the different soil layers decreased from the surface layer to the bottom of the soil layer under the different fertilization treatments. As shown in Figure 1, under the different fertilization levels, the available phosphorus content under the treatment distributed in the $0-40 \mathrm{~cm}$ soil layer was higher in the two irrigation modes. The main reason is that long-term fertilization leads to the massive accumulation of phosphorus in this layer. The regreening period is the key period of wheat growth, and the absorption and utilization of nutrients are enhanced. The nutrient was concentrated in the $0-60 \mathrm{~cm}$ soil layer of the wheat root distribution, while the available phosphorus content was lower in the soil layer below $60 \mathrm{~cm}$. Compared with the water-saving irrigation (B) treatment, the available phosphorus content in the surface soil under the traditional irrigation treatment was lower than that of the water-saving irrigation treatment, which may be because the demand for water in the regreening stage is relatively high and a higher irrigation amount allows the absorption of nutrients by wheat.

As shown in Figure 2, with regard to the regreening period, the available phosphorus content in the $0-60 \mathrm{~cm}$ soil layer at the jointing stage increased in the wheat jointing stage, and the rapidly available $P$ increased in the $60-80 \mathrm{~cm}$ soil layer. The root system of the wheat in the jointing stage began to grow downward, and the phosphorus in the soil accumulated within the root system range. In the wheat jointing stage, regardless of whether water-saving irrigation (A) or traditional irrigation (B) was used, the available P content in the $0-60 \mathrm{~cm}$ 


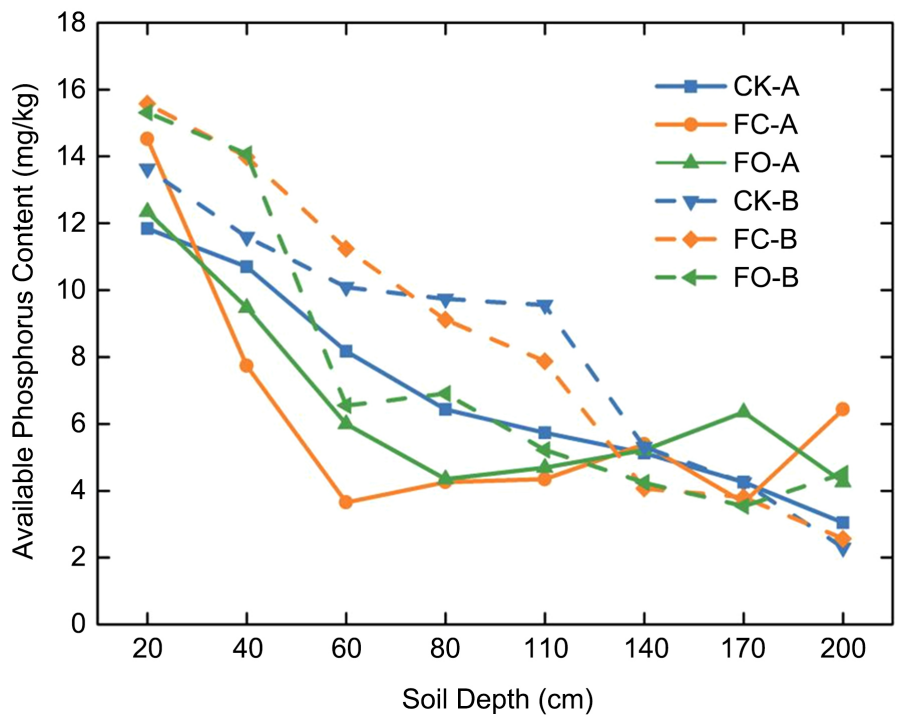

Figure 1. The soil available $\mathrm{P}$ content in the regreening stage.

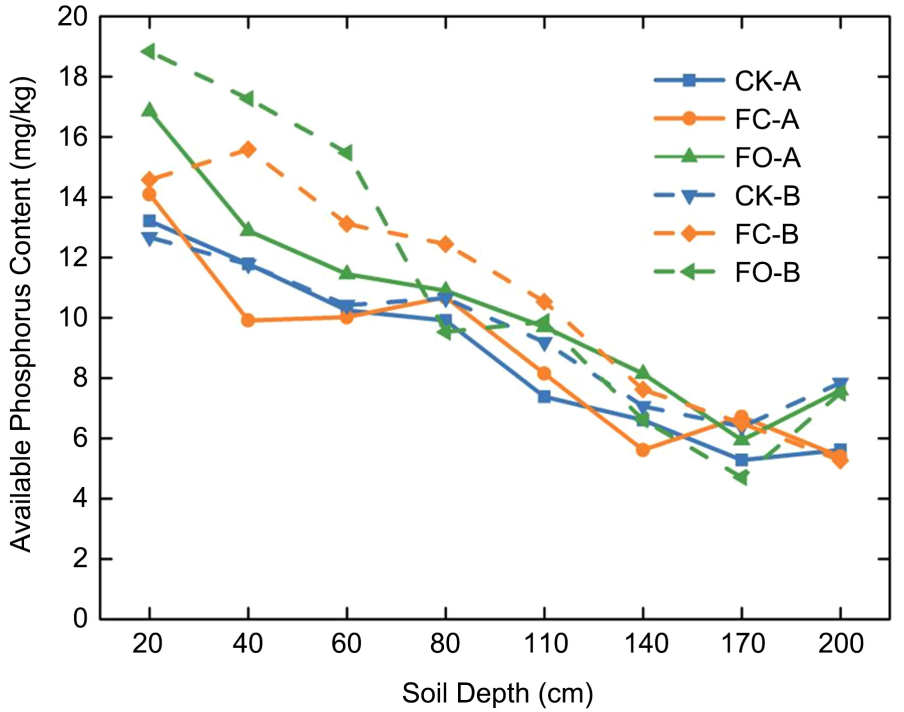

Figure 2. The soil available $\mathrm{P}$ content in the jointing stage.

soil layer decreased with increasing soil depth. In the wheat jointing stage, the rapidly available phosphorus content in the soil under the traditional irrigation treatment (A) was lower than that of the water-saving irrigation treatment (B), which may be because the water demand for wheat in the jointing stage is higher and broad irrigation is beneficial for the absorption of phosphorus fertilizer by wheat.

From the wheat jointing stage to the flowering stage (Figure 3), the soil temperature rate accelerated, and the content of the soil available phosphorus gradually increased. Regardless of whether traditional irrigation or water-saving irrigation was used, the available phosphorus content in the $0-20 \mathrm{~cm}$ soil layer followed the pattern of FO > FC, which indicates that the FC treatment in this stage can meet the fertilization requirements of wheat. 
After entering the grain filling stage (Figure 4), the available $\mathrm{P}$ content in the $0-40 \mathrm{~cm}$ soil layer increased, which was related to the demand quantity of $\mathrm{P}$ in the grain filling stage. In this stage, the climate was dry with a large evaporation capacity of soil moisture, and phosphorus accumulated in the soil surface under the treatment of phosphate fertilizer application level. Regardless of whether water-saving irrigation (B) or traditional irrigation (A) was used, the available phosphorus content in the $110-200 \mathrm{~cm}$ soil layer decreased, which was related to the migration of phosphorus in the soil.

In the mature stage of the wheat (Figure 5), compared to the grain filling stage, the available phosphorus content under each treatment decreased. This stage coincides with the rainy season, and the soil moisture content is high. The rapidly available phosphorus leached in the $140-200 \mathrm{~cm}$ soil layer.

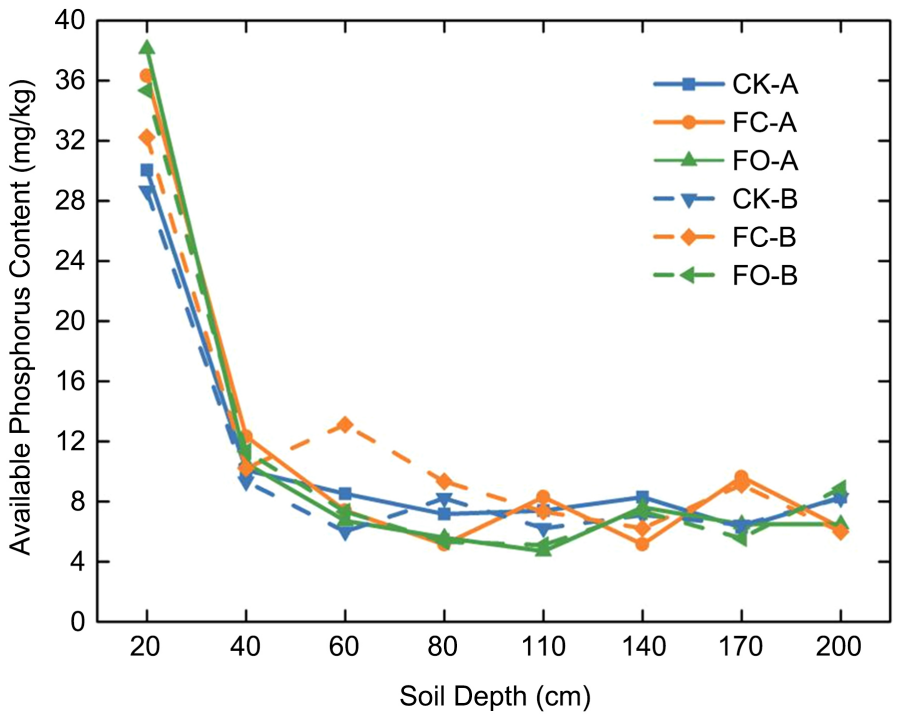

Figure 3. The soil available $\mathrm{P}$ content in the flowering stage.

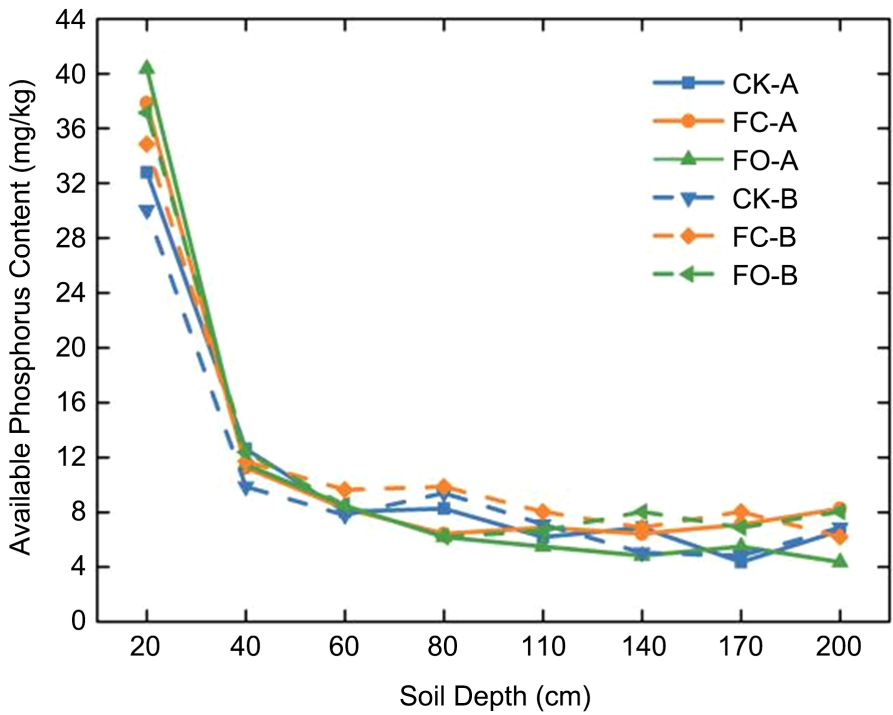

Figure 4. The soil available $\mathrm{P}$ content in the grain filling stage. 


\section{Phosphorus Absorption and Utilization by Plants}

The phosphorus absorption intensity of the winter wheat was also very small in the early stage, increasing rapidly after the regreening stage. The booting reaches the peak value in the grain filling stage. The difference is that after the jointing stage, the increase in the phosphorus absorption intensity of winter wheat is greater, which can reach 3.47 - 4.47 times that of the regreening stage; phosphorus accumulates in winter wheat, and the amount of nitrogen in the earlier growing stage of winter wheat gradually increases and rapidly increases after entering the regreening stage, which reaches the maximum value in the grain filling stage and then decreases significantly. The accumulation of phosphorus in wheat is always higher in the middle-late stages. Regardless of whether traditional irrigation (A) or water-saving irrigation (B) was used, the phosphorus content under the treatments followed the pattern of $\mathrm{FO}>\mathrm{FC}>\mathrm{CK}$ in the different growth stages (Table 3 ). The physical and chemical properties of the soil

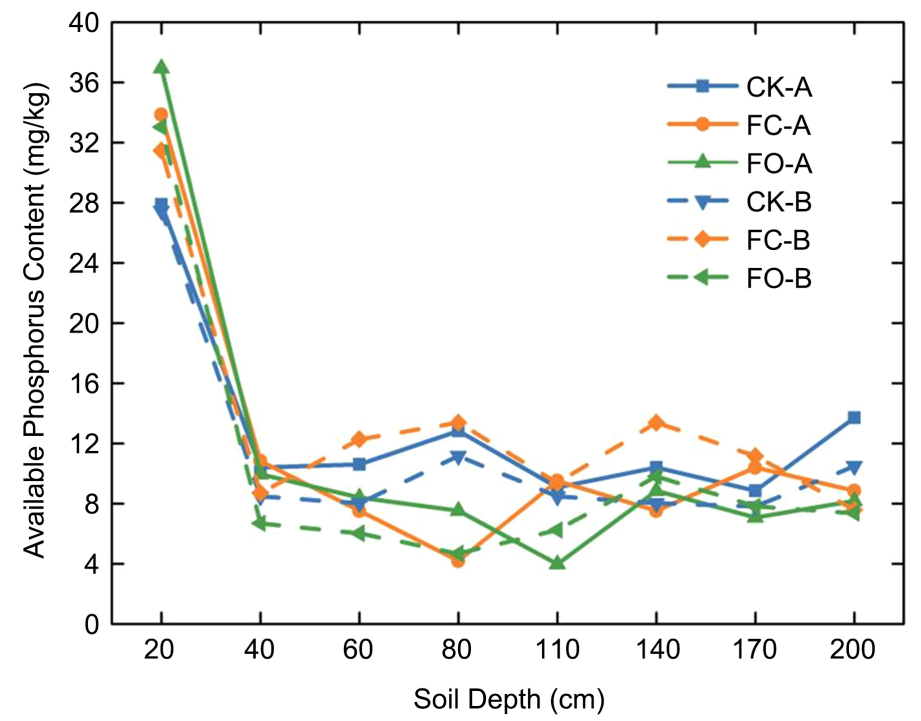

Figure 5. The soil available $\mathrm{P}$ content in the maturation stage.

Table 3. Uptake of phosphorus in wheat in the above-ground part.

\begin{tabular}{|c|c|c|c|c|c|c|}
\hline \multirow[b]{2}{*}{ Nutrient } & \multirow[b]{2}{*}{ Treatment } & \multicolumn{5}{|c|}{ Uptake of phosphorus in winter wheat $\left(\mathrm{kg} / \mathrm{hm}^{2}\right)$} \\
\hline & & $\begin{array}{c}\text { Regreening } \\
\text { stage }\end{array}$ & $\begin{array}{l}\text { Jointing } \\
\text { stage }\end{array}$ & $\begin{array}{c}\text { Flowering } \\
\text { stage }\end{array}$ & $\begin{array}{c}\text { Grain filling } \\
\text { stage }\end{array}$ & $\begin{array}{c}\text { Maturation } \\
\text { stage }\end{array}$ \\
\hline \multirow{6}{*}{$\mathrm{P}$} & CK-A & 28.63 & 4.93 & 13.73 & 22.03 & 25.02 \\
\hline & FC-A & 49.26 & 8.80 & 23.04 & 35.25 & 43.66 \\
\hline & FO-A & 55.71 & 9.21 & 23.13 & 38.06 & 47.44 \\
\hline & CK-B & 34.78 & 6.32 & 16.63 & 24.90 & 30.29 \\
\hline & FC-B & 52.31 & 10.35 & 27.44 & 37.89 & 47.08 \\
\hline & FO-B & 71.58 & 11.57 & 29.31 & 43.74 & 61.31 \\
\hline
\end{tabular}


changed after the application of the soil conditioner and accelerated the decomposition of the phosphate fertilizers, thus promoting the accumulation of phosphorus in the winter wheat. The average values of the nitrogen-phosphorus ratio accumulated under the treatments in the regreening, jointing, flowering, grain filling and harvesting stages were 9.70, 4.99, 5.00, 5.04, and 3.33, respectively. It can be seen that the nitrogen-phosphorus ratio accumulated in the winter wheat after the regreening stage continued to decrease, and the nitrogen-phosphorus ratio in the harvesting stage was significantly smaller than that of the previous stages, which indicates that after the wheat regreening stage, the nitrogen uptake by the winter wheat was relatively decreased, and the phosphorus uptake was relatively increased.

\section{Conclusion}

Water-saving irrigation and fertilizer management have been becoming a discipline of the Agriculture Science. We need to guarantee crops have enough fertilizer and water at different growing stage to make sure a good harvest, on the other hand, the most efficient fertilizer we have been used and the minimum water was demanded by different treatments must be considered by scientists. This experimental research found that water and fertilizer regulation can affect the absorption of nitrate in wheat, while excessive irrigation and no fertilization treatment will reduce nitrate absorption. In this study, the FC treatment increased the residual quantity of the soil nitrate in the winter wheat harvest stage compared with the CK treatment. In the wheat harvest stage, the accumulated amount of nitrate in the $120-200 \mathrm{~cm}$ soil layer can reach $137-200 \mathrm{~kg} / \mathrm{hm}^{2}$. For crop, the nitrate accumulation in the $0-90 \mathrm{~cm}$ soil layer can reach a minimum of $200 \mathrm{~kg} / \mathrm{hm}^{2}$ by using water-saving optimization of fertilization models, which reduces the possibility of large amounts of nitrate leaching in the crop growth stage.

\section{Acknowledgements}

The author would like to thank the help from Prof. Hongda Wen of Hebei Agricultural University and his research team. It was a great help from local famers for their continued support from Baiyang Lake during the 3 years of our research.

\section{Conflicts of Interest}

The authors declare no conflicts of interest regarding the publication of this paper.

\section{References}

[1] Wu, P.T. and Feng, H. (2005) A Preliminary Study on the Development Strategy of Water-Saving Agriculture in China. Transactions of the Chinese Society of Agricultural Engineering, 21, 152-157. 
[2] Wang, J.S., Jiao, X.Y., et al. (2016) Effects of Different Irrigation Periods and Nitrogen Application Rates on Water Use and Yield of Sorghum. Journal of Shanxi Agricultural Sciences, 6, 777-783.

[3] Arheimer, B. and Lidén, R. (2000) Nitrogen and Phosphorus Concentrations from Agricultural Catchments Influence of Spatial and Temporal Variables. Journal of Hydrology, 227, 140-159. https://doi.org/10.1016/S0022-1694(99)00177-8

[4] Li, J.R., Chen, L.D., Fu, B.J., et al. (2002) Temporal and Spatial Variation Characteristics of Non-Point Source Nitrogen in Surface Water of Yuqiao Reservoir. Scientia Geographica Sinica, 22, 238-242.

[5] Tapiavargas, M., Tiscarenolopez, M., Stone, J.J., et al. (2001) Tillage System Effects on Runoff and Sediment Yield in Hill Slope Agriculture. Field Crops Research, 69, 173-182. https://doi.org/10.1016/S0378-4290(00)00139-8

[6] Wang, X., Li, X.L., Zhang, M., et al. (2008) Reasons for Agricultural Non-Point Source Pollution and Strategies for Developing Sustainable Ecological Agriculture in Zigui County, the Three Gorges Reservoir Area. Bulletin of Agricultural Science and Technology, No. 12, 98-100.

[7] Matson, A.A., Naylor, R. and Ortiz-Monasterio, I. (1998) Integration of Environmental, Agronomic, and Economic Aspects of Fertilizer Management. Science, 280, 112-115. https://doi.org/10.1126/science.280.5360.112

[8] Wolfe, D.W., Henderson, D.W., Hsiao, T.C., et al. (1988) Interactive Water and Nitrogen Effects on Senescence of Maize. I. Leaf Area Duration, Nitrogen Distribution, and Yield. Agronomy Journal, 80, 859-864. https://doi.org/10.2134/agronj1988.00021962008000060004x

[9] Howell, T.A. (2001) Enhancing Water Use Efficiency in Irrigated Agriculture. Agronomy Journal, 93, 281-289. https://doi.org/10.2134/agronj2001.932281x

[10] Zhang, W.L., Tian, Z.X., Zhang, N., et al. (1996) Nitrate Pollution of Groundwater in Northern China. Agriculture, Ecosystems and Environment, 59, 223-231. https://doi.org/10.1016/0167-8809(96)01052-3

[11] Andraski, T.W., Bundy, L.G. and Brye, K.R. (2000) Crop Management and Corn Nitrogen Rate Effects on Nitrate Leaching. Journal of Environmental Quality, 29, 1095-1103. https://doi.org/10.2134/jeq2000.00472425002900040009x

[12] Varma, S.K., Malik, B.S., Nath, J., et al. (1976) Potassium Absorption as Affected by Nitrogen and Phosphorus Application under Varying Soil Moisture Regimes in Some Cereal and Leguminous Crops.

[13] Arnon, I. (1975) Physiological Principles of Dryland Crop Production. Physiological Aspects of Dryland Farming U.S. Gupta.

[14] Liu, X., Shao, L., Sun, H., et al. (2013) Responses of Yield and Water Use Efficiency to Irrigation Amount Decided by Pan Evaporation for Winter Wheat. Agricultural Water Management, 129, 173-180. https://doi.org/10.1016/j.agwat.2013.08.002

[15] Fang, Q.X., Ma, L., Green, T.R., et al. (2010) Water Resources and Water Use Efficiency in the North China Plain: Current Status and Agronomic Management Options. Agricultural Water Management, 97, 1102-1116.

https://doi.org/10.1016/j.agwat.2010.01.008

[16] Fang, Q.X., Chen, Y.H., Yu, Q., et al. (2007) Much Improved Irrigation Use Efficiency in an Intensive Wheat-Maize Double Cropping System in the North China Plain. Journal of Integrative Plant Biology, 49, 1517-1526. https://doi.org/10.1111/j.1672-9072.2007.00559.x

[17] Ji, Q., Sun, H.Y., Taraqqi, A.K. and Wang, X.D. (2014) Impact of Different Tillage 
Practices on Soil Organic Carbon and Water Use Efficiency under Continuous Wheat-Maize Binary Cropping System. Chinese Journal of Applied Ecology, 25, 1029-1035.

[18] Ju, X.T. and Gu, B.J. (2014) Current Status, Problems and Trends of Nitrogen Fertilizer Application in Farmland in China. Journal of Plant Nutrition and Fertilizer, 20, 783-795. 